\title{
報 告 III
}

\section{内科領域における Cefmetazole の臨床的検討}

長崎大学医学部第二内科学教室

原耕平

Key words: Cefmetazole, Clinical investigation

はじめに

近年グラム陰性桿菌による感染症が注目を浴 び，これと共に $\beta$-lactamase 産生菌が増加して， 治療上にも支障を来产症例があることが確かめら れてきている. Cefmetazole は三共株式会社によ つて開発されたが，本刘は $\beta$-lactamase 産生グラ ム陰性菌に抵抗性で, グラム陽性菌や嫌気性菌に も優れた抗菌力を有するセファマイシン系抗生物 質である。

わが国に括ける成績の集計が行なわれ，抗菌 力，吸収，排泄に関する成績はすでに前項に拈い て述べられているが，内科面に拈ける一括した臨 床集計成績をここに報告する。

Institutions Participating

Hokkaido Univ., 2nd Dept. of Internal Medicine National Sapporo Hospital, Respiratory Diseases Hirosaki Univ., 3rd Dept. of Internal Medicine Tohoku Univ., 1st Dept. of Internal Medicine

Tohoku Univ., Research Instiute for Tuberculosis and Leprosy, Internal Medicine

Niigata Univ., 2nd Dept. of Internal Medicine Suibarago Hospital, Internal Medicine

Shinrakuen Hospital, Internal Medicine

National Kasumigaura Hospital, Internal Medicine

Tokyo Univ., Institute of Medical Science, Internal Medicine

The Jikei Univ., 2nd Dept. of Internal Medicine

Tokyo Women's Medical College, Internal Medicine

Tokyo Kyosai Hospital, Internal Medicine

Tokyo Municipal Yoikuin Hospital, Internal Medicine

Kyorin Univ., 1st Dept. of Internal Medicine

Kawasaki City Hospital, Internal Medicine
Yokohama City Univ., 1st Dept. of Internal Medicine

Nagoya City Untv., 1st Dept. of Internal Medicine

Tokai Teishin Hospital, Internal Medicine

Toyama Prefectural Central Hospital, Internal Medicine

Kyoto Univ., Research Institute for Tuberculosis and Thoracic Diseases, 1st Dept. of Internal Medicine

Osaka City Univ., 1st Dept. of Internal Medicine

Kansai Medical College, 1st Dept. of Internal Medicine

Hoshigaoka Kosei Nenkin Hospital, Internal Medicine

Kawasaki Medical College, Respiratory Diseases

Tokushima Univ., 3rd Dept. of Internal Medicine

Kyushu Univ., 1st Dept. of Internal Medicine

Kyushu Univ., Research Institute for Thoracic Diseases, Internal Medicine

Nagasaki Univ., 2nd Dept. of Internal Medicine

Nagasaki Univ., Institute of Tropical Medicine, Internal Medicine

Kumamoto Univ., 1st Dept. of Internal Medicine

\section{使用症例および使用方法}

1. 解析対象症例

Table 1に示したごとく，使用した症例は414例 めつた。このうら適切な使用と考光られなかつた 44例を除外した370例について，臨床効果に関す る解析を行つた。

除外症例は, 他の抗生物質の併用により効果の 判定が行ない得なかつた19例，癌などの基礎的疾 患のため死亡した 3 例, マイコプラスマ感染症と 診断された（補体結合反応で 4 倍以上の上昇を認 め, 且つ回復期の抗体価が64倍以上のもののみを 確診例とした） 6 例，本剤使用後肺結核と殓断さ 
Table 1 Number of Cases Analysed

\begin{tabular}{l|c|c}
\hline \multicolumn{1}{c|}{ Diseases } & $\begin{array}{l}\text { No. of cases } \\
\text { administered }\end{array}$ & $\begin{array}{l}\text { No. of cases } \\
\text { analysed }\end{array}$ \\
\hline $\begin{array}{l}\text { Respiratory Tract } \\
\text { Infection }\end{array}$ & 240 & 213 \\
\hline $\begin{array}{l}\text { Urinary Tract } \\
\text { Infection }\end{array}$ & 113 & 113 \\
\hline Bile Duct Infection & 25 & 25 \\
\hline Bacteremia & 18 & 13 \\
\hline Others & 18 & 6 \\
\hline \multicolumn{1}{c}{ Total } & 414 & 370 \\
\hline Not Analysed Cases : & $\begin{array}{l}\text { Other antibiotics used } \\
\text { Death by malignancy } \\
\text { Diagnosed as mycoplasma } \\
\text { infection } \\
\text { Diagnosed as pulmonary } \\
\text { tuberculosis } \\
\text { Other reasons }\end{array}$ & $\begin{array}{r}6 \\
11\end{array}$
\end{tabular}

Table 2 Sex and Age Distribution in the cases

\begin{tabular}{c|c|c|c}
\hline Age by Decade & Male & Female & $\begin{array}{c}\text { Total } \\
\text { cases }\end{array}$ \\
\hline-19 & 4 & 3 & 7 \\
\hline $20-29$ & 6 & 24 & 30 \\
\hline $30-39$ & 15 & 13 & 28 \\
\hline $40-49$ & 33 & 25 & 58 \\
\hline $50-59$ & 30 & 37 & 67 \\
\hline $60-69$ & 54 & 40 & 94 \\
\hline $70-79$ & 40 & 25 & 65 \\
\hline $80-89$ & 12 & 8 & 20 \\
\hline $90-$ & & 1 & 1 \\
\hline Total & 194 & 176 & 370 \\
\hline
\end{tabular}

れた 5 例，その他，肺癌や肝癌があつて重篤な経 過をたどつたため效果が判定しかねたもの7例 之, 不明熱で䛦断がつかなかつたもの 2 例, 副作 用のため投薬を中止し效果の判定ができなかつた 2 例を含む合計 44 例であつた。

2. 症例の構成

その性別，年龄別分布を Table 2 に示した。

男女注注同数を占めたが，男性の方がやや高粭 層に分布している傾向が伺われた。60歳代に最も 多く分布し，次いで50歳代，70歳代が多くを占め ていて，使用例が高齢者に片寄つている傾向がみ られた。このことは，その臨床効果を判定すべき 際に参考にすべきことと考えられた。

3. 使用法

その投与法之, 投与量, 投与日数についての関 連を Table 3和よび Table 4亿示した。

Table 3 に示したごとく，370例中71例（19.2 \%) が筋注で使用されたが，これらの例は $1.0 \mathrm{~g}$ の投与例が最も多く, 次いで $1.5 \sim 2.0 \mathrm{~g}$ の投与 例で，その $98.6 \%$ でが $2.0 \mathrm{~g}$ 以下の投与であっ た。これに対し，370例中の299例 $(80.8 \%)$ まで は何等かの形の静脈投与が行なわれ，これらの例 では $2.0 \mathrm{~g}$ の投与が最も多く, 次いで $4.0 \mathrm{~g}$ の投与 で，2.0g 以上の投与がその $90.3 \%$ 占めた。

Table 4 に示したごとく，これらの投与で 1 回のみの投与に終つたものは370例中 24 例にすぎ ず，残りの全例は 1 日 2 回以上の形で投与が行な われ，なかでも 2 回の投与が最も多く症例の 77.3

Table 3 Daily Dosis by Administration Method

\begin{tabular}{|c|c|c|c|c|c|c|c|}
\hline & $\begin{array}{l}\text { drip } \\
\text { infusion } \\
(d-i)\end{array}$ & $\begin{array}{c}\text { intravenous } \\
\text { (i.v) }\end{array}$ & $\begin{array}{l}\text { intra- } \\
\text { muscular } \\
\text { (i.m) }\end{array}$ & $\begin{array}{c}\text { d.i } \\
\left({ }^{+} \text {i.m }\right)\end{array}$ & $\begin{array}{c}\mathrm{d} . \mathrm{i} \\
\left({ }^{+} \mathrm{i} . \mathrm{m}\right)\end{array}$ & $\begin{array}{c}\text { i.v } \\
\left({ }^{+} \mathrm{i} . \mathrm{m}\right)\end{array}$ & $\begin{array}{l}\text { Total } \\
\text { cases }\end{array}$ \\
\hline $0.5 \mathrm{~g} / \mathrm{day}$ & & & 1 & & & & 1 \\
\hline 1.0 & 14 & 11 & 34 & & & & 59 \\
\hline 1.5 & & 2 & 19 & & 1 & 1 & 23 \\
\hline 2.0 & 131 & 34 & 13 & 2 & 4 & & 184 \\
\hline 3.0 & 6 & 1 & & 2 & & & 9 \\
\hline 4.0 & 39 & 2 & 1 & & 1 & & 43 \\
\hline 6.0 & 5 & 1 & & 1 & 1 & & 8 \\
\hline Unsettled & 32 & 6 & 3 & 1 & 1 & & 43 \\
\hline Total & 227 & 57 & 71 & 6 & 8 & 1 & 370 \\
\hline
\end{tabular}


Table 4 Daily Dosis and Times

\begin{tabular}{|c|c|c|c|c|c|c|}
\hline & Once & Twice & 3 times & 4 times & Irregular & $\begin{array}{l}\text { Total } \\
\text { cases }\end{array}$ \\
\hline$-0.5 \mathrm{~g} /$ day & 1 & & & & & 1 \\
\hline-1.0 & 5 & 54 & & & & 59 \\
\hline-1.5 & & 2 & 21 & & & 23 \\
\hline-2.0 & 16 & 164 & & 3 & 1 & 184 \\
\hline-3.0 & & 5 & 4 & & & 9 \\
\hline-4.0 & & 42 & & & 1 & 43 \\
\hline-6.0 & & 3 & 4 & & 1 & 8 \\
\hline Unsettled & 2 & 17 & & 1 & 23 & 43 \\
\hline Total & 24 & 287 & 29 & 4 & 26 & 370 \\
\hline
\end{tabular}

Table 5 Clinical Effect in the Cases With or Without Underlying Diseases

A Total cases

\begin{tabular}{|c|c|c|c|c|c|c|}
\hline & Cases & $\begin{array}{l}\text { Remarkable } \\
\text { improvement }\end{array}$ & Improvement & $\begin{array}{l}\text { No } \\
\text { improvement }\end{array}$ & Undefinite & $\begin{array}{l}\text { Effective } \\
\text { rate }(\%)\end{array}$ \\
\hline Respiratory Tract Infection & 213 & 35 & 134 & 36 & 8 & 82.4 \\
\hline Urinary Tract Infection & 113 & 29 & 67 & 13 & 4 & 88.1 \\
\hline Bile Duct Infection & 25 & 5 & 13 & 6 & 1 & 75.0 \\
\hline Bacteremia & 13 & 3 & 6 & 4 & & 69.2 \\
\hline Others & 6 & & 4 & 2 & & 66.7 \\
\hline Total & 370 & 72 & 224 & 61 & 13 & 82.9 \\
\hline
\end{tabular}

B Cases with underlying Diseases

\begin{tabular}{l|c|c|c|c|c|c}
\hline & Cases* & $\begin{array}{l}\text { Remarkable } \\
\text { improvement }\end{array}$ & $\begin{array}{l}\text { Improvement } \\
\text { No }\end{array}$ & $\begin{array}{l}\text { improvement } \\
\text { implefinite }\end{array}$ & $\begin{array}{l}\text { Effective } \\
\text { rate }\end{array}$ \\
\hline Respiratory Tract Infection & 89 & 8 & 56 & 22 & 3 & 74.4 \\
\hline Urinary Tract Infection & 67 & 10 & 40 & 13 & 4 & 79.4 \\
\hline Bile Duct Infection & 18 & 4 & 8 & 5 & 1 & 70.6 \\
\hline Bacteremia & 9 & 3 & 4 & 2 & 77.8 \\
\hline Others Total & 3 & & 3 & & & 100.0 \\
\hline
\end{tabular}

C Cases without Underlying Diseases

\begin{tabular}{|c|c|c|c|c|c|c|}
\hline & Cases* & $\begin{array}{l}\text { Remarkable } \\
\text { improvement }\end{array}$ & Improvement & $\begin{array}{l}\text { No } \\
\text { improvement }\end{array}$ & Undefinite & $\begin{array}{l}\text { Effcetive } \\
\text { rate }(\%)\end{array}$ \\
\hline Respiratory Tract Infection & 121 & 26 & 77 & 13 & 5 & 88.8 \\
\hline Urinary Tract Infection & 45 & 19 & 26 & & & 100.0 \\
\hline Bile Duct Infection & 6 & 1 & 4 & 1 & & 83.3 \\
\hline Bacteremia & 4 & & 2 & 2 & & 50.0 \\
\hline Others & 3 & & 1 & 2 & & 33.3 \\
\hline Total & 179 & 46 & 110 & 18 & 5 & 89.7 \\
\hline
\end{tabular}

* Exclude 5 Uncertained Cases of Underlying Diseases

\%を占めた. 3 回ないし 4 回の投与が行なわれた ものの多くは筋注投与であつた。

表には示さなかつたが，その大部分は 2 週間の 観察で効果が判定されたが，3週ないしはそれ以
上， 1 週間使用例がこれに次いだ。

\section{臨床効果}

1. 疾患群別による臨床効果

この成績を一括して Table 5 に示した。 
Table 6 Clinical Effect of the Diseases

\begin{tabular}{|c|c|c|c|c|c|c|c|}
\hline & & Cases & $\begin{array}{l}\text { Remarkable } \\
\text { improvemeut }\end{array}$ & Improvement & | & Undefinite & $\begin{array}{l}\text { Effective } \\
\text { rate }(\%)\end{array}$ \\
\hline \multirow{8}{*}{ 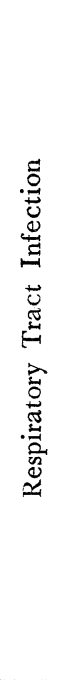 } & $\begin{array}{l}\text { Upper Resp. Tract Infection } \\
\text { Acute bronchitis }\end{array}$ & $\begin{array}{l}4 \\
7\end{array}$ & $\begin{array}{l}1 \\
1\end{array}$ & $\begin{array}{l}1 \\
6\end{array}$ & 2 & & $\begin{array}{r}50.0 \\
100.0\end{array}$ \\
\hline & Subtotal & 11 & 2 & 7 & 2 & & 81.8 \\
\hline & $\begin{array}{l}\text { Chronic Bronchitis } \\
\text { Panbronchiolitis } \\
\text { Bronchiectasis }\end{array}$ & $\begin{array}{r}26 \\
1 \\
21\end{array}$ & 3 & 11 & $\begin{array}{l}5 \\
1 \\
6\end{array}$ & 1 & $\begin{array}{c}80.8 \\
0 \\
70.0\end{array}$ \\
\hline & Subtotal & 48 & 5 & 30 & 12 & 1 & 74.5 \\
\hline & $\begin{array}{l}\text { Pneumonia } \\
\text { Lung Abscess } \\
\text { Pyothorax }\end{array}$ & $\begin{array}{r}104 \\
24 \\
5\end{array}$ & $\begin{array}{r}22 \\
5 \\
1\end{array}$ & $\begin{array}{r}69 \\
12 \\
2\end{array}$ & $\begin{array}{r}10 \\
6 \\
1\end{array}$ & $\begin{array}{l}3 \\
1 \\
1\end{array}$ & $\begin{array}{l}90.1 \\
73.9 \\
75.0\end{array}$ \\
\hline & Subtotal & 133 & 28 & 83 & 17 & 5 & 86.7 \\
\hline & Complicated Pulmonary Infection & 21 & & 14 & 5 & 2 & 73.7 \\
\hline & Total & 213 & 35 & 134 & 36 & 8 & 82.4 \\
\hline \multirow{6}{*}{ 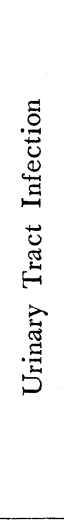 } & $\begin{array}{l}\text { Acute Cystitis } \\
\text { Acute Pyelonephritis } \\
\text { Acute Urinary Tract Infection }\end{array}$ & $\begin{array}{l}10 \\
37 \\
10\end{array}$ & $\begin{array}{r}2 \\
16 \\
1\end{array}$ & $\begin{array}{r}7 \\
19 \\
7\end{array}$ & $\begin{array}{l}1 \\
1 \\
2\end{array}$ & 1 & $\begin{array}{l}90.0 \\
97.2 \\
80.0\end{array}$ \\
\hline & Subtotal & 57 & 19 & 33 & 4 & 1 & 92.9 \\
\hline & $\begin{array}{l}\text { Chronic Cystitis } \\
\text { Chronic Pyelonephritis } \\
\text { Chronic Urinary Tract Infection }\end{array}$ & $\begin{array}{l}13 \\
18 \\
14\end{array}$ & $\begin{array}{l}4 \\
5 \\
1\end{array}$ & $\begin{array}{r}6 \\
17 \\
10\end{array}$ & $\begin{array}{l}3 \\
3 \\
3\end{array}$ & 3 & $\begin{array}{l}76.9 \\
88.0 \\
78.6\end{array}$ \\
\hline & Subtotal & 55 & 10 & 33 & 9 & 3 & 82.7 \\
\hline & Others & 1 & & 1 & & & 100.0 \\
\hline & Total & 113 & 29 & 67 & 13 & 4 & 88.1 \\
\hline \multirow[t]{2}{*}{ 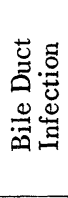 } & $\begin{array}{l}\text { Cholecystitis } \\
\text { Cholangitis } \\
\text { Others }\end{array}$ & $\begin{array}{r}15 \\
9 \\
1\end{array}$ & $\begin{array}{l}3 \\
2\end{array}$ & $\begin{array}{r}10 \\
3\end{array}$ & $\begin{array}{l}1 \\
4 \\
1\end{array}$ & 1 & $\begin{array}{c}92.9 \\
55.6 \\
0\end{array}$ \\
\hline & Total & 25 & 5 & 13 & 6 & 1 & 75.0 \\
\hline \multirow{2}{*}{ 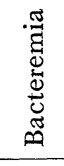 } & $\begin{array}{l}\text { Sepsis } \\
\text { Subacute bacterial endocarditis }\end{array}$ & $\begin{array}{r}11 \\
2\end{array}$ & 3 & $\begin{array}{l}5 \\
1\end{array}$ & $\begin{array}{l}3 \\
1\end{array}$ & & $\begin{array}{l}52.7 \\
50.0\end{array}$ \\
\hline & Total & 13 & 3 & 6 & 4 & & 69.2 \\
\hline \multicolumn{2}{|r|}{ Others } & 6 & & 4 & 2 & & 66.7 \\
\hline & Total & 370 & 72 & 224 & 61 & 13 & 82.9 \\
\hline
\end{tabular}


呼吸器感染症に使用したものが最も多く213例 を占めたが，著効，有効を含めた使用症例の有効 率は $82.4 \%$ であつた，基礎疾患を有するものでは $74.4 \%$ 有効率であつたのに，基礎疾患を有しな いものでは88.8\%の成績を示し，且つ著効例がか なり多くの割合を占めた。この傾向は尿路感染症 に抒いても認められ，基礎疾患のめるものでは $79.4 \%$ でめたのに, 基礎疾患を有しないるので は100\%で，全体で88.1\%の成績を示し，また胆 道感染症に执いても，基礎疾患のあるものは70.6 \%，ないものでは83.3\%で，全体で75.0\%の成績 を示した。菌血症では症例数が少なかつたが， 69.2\%の有效率を示した。その他の 6 例は, 腸炎 が 2 例, 腹膜炎 2 例, それに副睪丸炎之肛門周囲 膿瘍の各 1 例が含まれていたが，その 4 例（66.7 \%) 飞有効の成績が得られた。

以上, 解析対象症例 370 例に扣いて, 判定不能 例13例を除く357例に括ける有效和よび著効例の 合計は296例で, その有効率は $82.9 \%$ と, 従来の セファロスポリン系抗生剤の成績に比べてかなり すぐれた成績を示した。

\section{2. 疾患別臨床効果}

さらに詳しく細別した成績を Table 6 亿示し た。

先ず, 呼吸器感染症では, 上気道感染症 11 例の らち, ウイルス性感染と思われる上気道炎 2 例を 除く全例に有効の成績を得た。この系統で最も多 くを占めた肺资や肺化膿症，膿胸を含む肺の実質 性炎症133例飞招いては，年の $86.7 \%$ に有効ない し著効の成績が得られ，とくに肺炎に拈いては実 に90.1\%の有効率がみられた。慢性気管支炎, 慢 性びまん性沉細気管支炎, 気管支拡張症を含告慢 性気道感染症に招いては，47例中35例（74.5\%) に有效以上の成績が得られ，また肺癌への感染を 主とする併発肺感染例19例においても14例にまで 有効の成績 (有効率73.7\%) が得られ，この両者 に招いて，著効例は少なかつたものの，有効率が 高率であつたことが，呼吸器感染症全体に特ける 有効率を著しく高めたものと考兄られた。

前述したごとく，尿路感染症に扔いても良好な
臨床効果が得られたが，これを急性と慢性に分け たところ，前者で平均 $92.9 \%$ ，後者で平均 $82.7 \%$ の有効率が得られた。胆道感染症では, 胆囊炎で 92.9\%の高率の有効率が得られ，これに対して胆 管炎では55.6\%の有効率であつた。

菌血症では13例中 4 例が無效であつた，そのう らの 2 例は再生不良性貧血および僧帽弁置換術後 といら基礎疾患が存在していたが，他の 2 例はい ずれも基礎疾患が存在せず，起炎菌は S. aureus であつて，菌は消失したにもかかわらず，臨床症 状は改善しないものであつた。有効 9 例中の 5 例 にまで菌が検出され，E. coli が 4 例, S. epidermidis が 1 例に検出されたがこれらはいずれも消 失し, 症状も改善をみた。

3. 起炎菌別細菌学的効果ならびに臨床効果 すべての感染症を一括して, 菌が検出されたも のについて，本剤投与後の推移を Fig. 1 亿示し た。グラム陽性菌では，試験管内で感受性と考 えら机るStaphylococcus, Streptococcus に対して 82.3〜 100\%の菌消失がみられたことは当然とし ても, S. faecalis にも5 例中全例に菌の消失が

Fig. 1 Eradication Effect of Isolated Bacteria

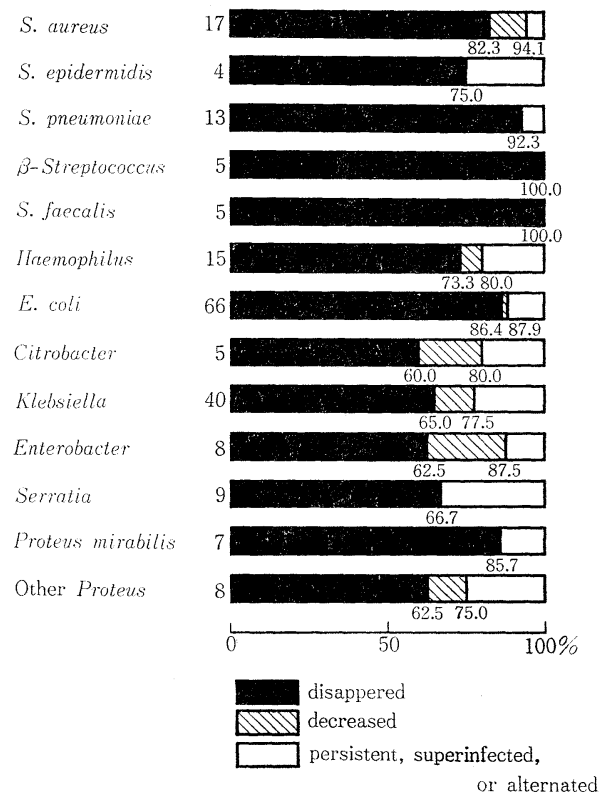

or alternated 
Table 7 Clinical Effect of the Diseases Caused by Each Pathogens

\begin{tabular}{|c|c|c|c|c|c|c|}
\hline \multirow{2}{*}{ Pathogens } & \multirow{2}{*}{ Cases } & \multicolumn{4}{|c|}{ Clinical effect } & \multirow{2}{*}{$\begin{array}{l}\text { Effective } \\
\text { rate }(\%)\end{array}$} \\
\hline & & \begin{tabular}{|l|} 
Remarkable \\
improvement
\end{tabular} & Improvement & $\begin{array}{l}\text { No } \\
\text { improvement }\end{array}$ & Undefinite & \\
\hline S. aureus & 11 & 3 & 5 & 3 & & 72.7 \\
\hline S. epidermidis & 4 & 1 & 2 & 1 & & 75.0 \\
\hline S. pneumoniae & 10 & 3 & 7 & & & 100.0 \\
\hline$\beta$-Streptococcus & 4 & & 4 & & & $100^{\circ}$. \\
\hline S. faecalis & 4 & & 3 & 1 & & 75.0 \\
\hline Subtotal & 33 & 7 & 21 & 5 & & 84.8 \\
\hline Haemophilus & 15 & 3 & 10 & 2 & & 86.7 \\
\hline E. coli & 62 & 17 & 39 & 6 & & 90.3 \\
\hline Citrobacter & 3 & 1 & 1 & & 1 & 100.0 \\
\hline Klebsiella & 34 & 5 & 16 & 11 & 2 & 65.6 \\
\hline Enterobacter & 9 & 2 & 6 & 1 & & 88.9 \\
\hline Serratia & 6 & 1 & 5 & & & 100.0 \\
\hline Proteus mirabilis & 6 & 1 & 4 & 1 & & 83.3 \\
\hline Other Proteus sp. & 4 & & 3 & 1 & & 75.0 \\
\hline P. aeruginosa & 4 & 1 & 2 & 1 & & 75.0 \\
\hline Other GNR & 4 & 2 & 2 & & & 100.0 \\
\hline Subtotal & 147 & 33 & 88 & 23 & 3 & 84.0 \\
\hline Peptostreptococcus & 1 & 1 & & & & 100.0 \\
\hline Mixed infection & 25 & 4 & 16 & 3 & 2 & 87.0 \\
\hline Total & 206 & 45 & 125 & 31 & 5 & 84.6 \\
\hline
\end{tabular}

みられた。グラム陰性桿菌に対しては, Serratia, Klebsiella, E. coli, Citrobacter, Proteus K60.0 $86.4 \%$ 菌消失がみられ, Enterobacter に拉いて もその $62.5 \%$ に菌の消失がみられた。その試験 管内抗菌力を反映して, E. coli や Haemophilus のみならず, Klebsiella, Serratia, Enterobacter な どの菌にもかなりの消失をみた。検出された菌が 必ずしも起炎菌と結びつかないにしても，その消 失率は高率で臨床的にも参考になるものと考えら れた。

そこで起炎菌別にその臨床効果を検討してみた ところ, Table 7 に示したよらな成績を得た。グ ラム陽性菌が検出された例で $84.8 \%$ ，グラム㓌性 菌が検出された例で $84.0 \%$ の成績を得たが，これ をさらに症例数の関係から，呼吸器系と尿路系の 感染症についてのみ, 疾患別に細菌別の臨床効果
に検討を加えてみた。 夫々の例数が少なく，明ら かな結論を得るには至らなかつたが，呼吸器系で グラム陽性菌に95.7\%，グラム陰性菌に76.1\%， 尿路系でグラム陽性菌に $83.3 \%$ ，グラム院性菌に 89.5\%の有効率が得られた。ここに特いても， Serratia, Klebsiella などの菌消失が，他のセファ ロスポリン系抗生剤に比し高率にみられた。

4. 1 日投与量および投与法別による臨床効果 その成績を Fig. 2 に示した。必ずしも投与量 の増加によつて有効率が上昇するといら成績は得 られなかつたが，これは疾病の軽重や起炎菌など との条件に差があるためと思われた。 また投与法 別による臨床効果の発現率をみたところ，その評 価に耐学得る数を有する点洅群227例中では84.9 $\%$, 静注群57例では $80.4 \%$, 筋注群71例では77.6 \%と，笳注群でやや劣る成績がみられた。 
Fig. 2 Summary of Clinical Effect Based on Daily Dosis

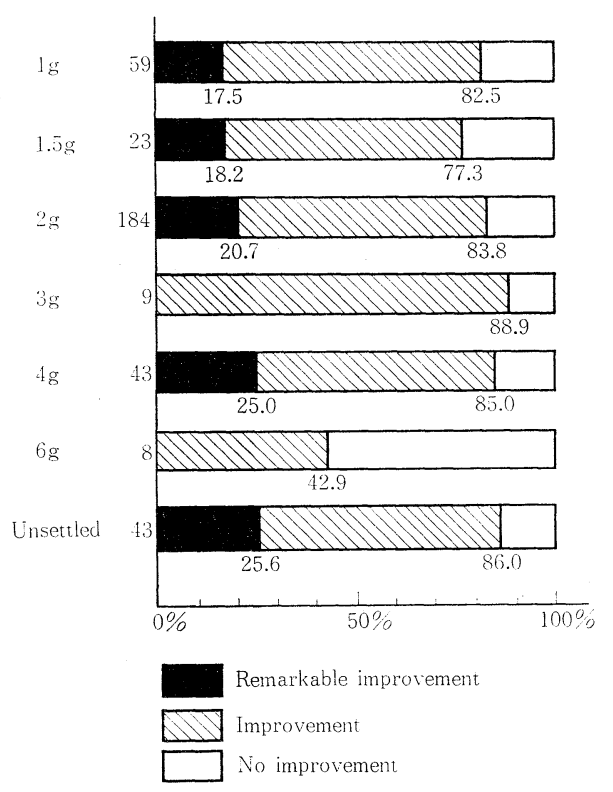

まとめ

Cefmetazole は，グラム陽性球菌をはじめ，グ ラム陰性桿菌に対しても幅広い抗菌力を有し, E. coli はもちろん, Serratia, Klebsiella, 各種の Proteus, Citrobacter にも, 他のセファロスポリ ン系抗生剤と異なつて強い抗菌力を示すことが知 られている。

この傾向は内科系臨床使用例にも反映され，患 者からのこれら各種のグラム院性桿菌の消失が, 本剂使用後60～85\%の比率で認められた.

従つてこれら各種のグラム陰性桿菌に基ずくと 思われる慢性の尿路感染症や慢性気道感染症に拉 いても極めてよい成績が得られ，これが総合的な 有効率を高める原因となつて，評価を行ない得た 357 例中の 296 例 $(82.9 \%)$ に有効の成績が得られ た。この成績は，全国の集計の段階でまとめられ た既存のセファロスポリン系抗生剤の内科系に和 ける総合成績 $64.9 \sim 84.0 \%$ 有効率のなかでは， 極めて高位にランクされるべきものである.

Report III. In the Field of Internal Medicine

\section{Kohei HARA}

Second Department of Internal Medicine, Nagasaki University, School of Medicine

Cefmetazole has a wide spectrum of antibacterial activity not only against gram-positive bacteria but also against gram-negative bacteria including E. coli, Serratia, Klebsiella, Proteus and Citrobacter, against which other antibiotics of Cephalosporine group are ineffective. The antibacterial activity of cefmetazole has been proven in the clinical cases in the field of internal medicine: following the administration of cefmetazole, eradication of gram-negative bacilli at the rate of 60 to $85 \%$ was observed in our study.

Consepuently, excellent clinical responses were noted in chronic infections of urinary and respiratory tracts caused by gramnegative bacilli. We have obtained the high efficacy rate of $82.9 \%$ (296 effective cases out of total 357 cases) with cefmetazole which should be rated as one of the most effective among known Cephalosporine antibiotics, as the overall efficacy rate of the antibiotics of this group applied to the patients in the field of internal medicine was between 64.9 and $84.0 \%$ which was obtained in the nation-wide survey. 